\title{
Spectral analysis of flowers used by nectar-feeding birds in an urban area in Southeastern Brazil
}

\author{
Toledo, MCB. ${ }^{\mathrm{a} *}$ and Donatelli, $R J .{ }^{\mathrm{b} *}$ \\ anstituto de Biociências, Universidade de Taubaté - UNITAU, Av. Tiradentes, 500, CEP 12010-180, Taubaté, SP, Brazil \\ bDepartamento de Ciências Biologicas, Universidade Estadual Paulista "Júlio de Mesquita Filho" - UNESP, \\ Av. Engenheiro Luiz Edmundo C. Coube, CEP 17033-360, Bauru, SP, Brazil \\ *e-mail: cecilia@unitau.br, rjdonat@fc.unesp.br
}

Received June 23, 2009 - Accepted April 20, 2010 - Distributed October 31, 2010

(With 2 figures)

\begin{abstract}
The objective of this study was to determine the spectral characteristic of nectar-producing flowers visited by nectarivorous birds in urban areas. This study was carried out in the central area of the city of Taubaté, in the northeast of the State of São Paulo. The sample areas included green areas, such as squares and parks, and the vegetation of streets and avenues. Twelve plant species were recorded with flowers visited by five nectar-feeding birds. The most visited flower species were those that reflected in long wavelengths $(>600 \mathrm{~nm})$. The study discussed the birds' detection capability due to the tetrachromatic vision of nectar-feeding birds and the conspicuity of flowers in urban environments. Finally, the study assessed the scarcity of plants attractive to nectar-feeding birds and the need for a management strategy to favour these species and biodiversity in urban areas.
\end{abstract}

Keywords: urban areas, wavelenght, flower colors, reflectance, nectar-feeding birds.

\section{Análise espectral de flores utilizadas por aves nectarívoras em uma área urbana no Sudeste do Brasil}

\section{Resumo}

Análise espectral de flores utilizada por aves nectarívoras em áreas urbanas. O objetivo deste trabalho foi estabelecer a característica espectral das flores produtoras de néctar visitadas por nectarívoros em áreas urbanas. Este estudo foi desenvolvido na região central do município de Taubaté, no nordeste do Estado de São Paulo. As áreas amostradas incluíram espaços verdes, tais como praças e parques e a vegetação das ruas e avenidas. Foram registradas 12 espécies de plantas utilizadas por cinco espécies de aves nectarívoras. As espécies de flores mais visitadas foram aquelas que refletiram em comprimento de onda longos (>600 nm). Foi discutida a capacidade de detecção das aves em função de visão tetracromática das aves nectarívoras e da conspicuidade das flores em ambientes urbanos. Finalmente, foi abordado o problema da escassez de plantas atrativas para aves nectarívoras nas áreas verdes urbanas e a necessidade de se aumentar a quantidade dessas espécies de plantas para incrementar a biodiversidade em regiões urbanas.

Palavras-chave: áreas urbanas, comprimento de onda, cor de flores, refletância, aves nectarívoras.

\section{Introduction}

The impact of urban development on the structure and function of an area's vegetation is dramatic. The landscape of an urban centre consists of a mosaic of built-up areas, gardens, parks, yards and rare fragments of native forest (Davis and Glick, 1978; French et al., 2005). Native vegetation areas are usually replaced by other exotic and native species with better aesthetics, landscaping and commercial performance (Beissinger and Osborne, 1982; DeGraaf, 1985). Given the increase in urbanised landscapes, the conservation of organisms within this modified habitat is important for the regional conservation of biodiversity, and to the development of

conservation ethics in the community through improved interactions with wildlife.

Many studies corroborate the positive relationship between native birds diversity and the occurrence of native plant species in urban areas (e.g. Clergeau et al., 1998; Mendonça and Anjos, 2005). In other words, the permanence of a native bird population is conditioned by the availability of resources that enable reproduction and feeding. Nectar-feeding birds / nectarivorous birds are conspicuous in urban and suburban areas (Mendonça and Anjos, 2005; Toledo and Moreira, 2008). With regard to New World nectarivorous birds, especially in tropical areas, 
Trochilidae (hummingbirds) are the main pollinating species, but there are other flower visitors, such as the Thraupidae (tanagers), Icteridae (blackbirds), Contigidae (cotingas), Picidae (woodpeckers), Emberizidae (flowerpiercers) and Coerebidae (honeycreepers), which are adapted to a nectar diet (Rocca and Sazima, 2008). However, little is known about the eating habits of these other flower-visiting species (Mata and Bosque, 2004). Some species are common in urban and suburban areas, especially Eupetomena macroura (Gmelin, 1788), Thalurania glaucops, Amazilia lactea (Lesson, 1832), Thraupis sayaca (Linnaeus, 1766) and Coereba flaveola (Lineu, 1758), the three first being Trochilidae, followed by Thraupidae and Coerebidae, respectively (Sick, 1994; Mendonça and Anjos, 2005; Toledo and Moreira, 2008).

Many native nectar-feeding birds present in urban areas use native and exotic plant species. A flower visit may be related to nectar production characteristics, resource configuration (colour and shape), and the birds' ability to recognise the resource (Green, 1984). A study carried out by French et al. (2005) with nectar production and nectar-feeding birds' visitation to native and exotic plant species in Australia showed that there was no correlation between the amount of nectar and the number of flower visits. However, there was a slight tendency to higher visitation rate to native plant species.

But what makes a bird investigate a native or exotic flower? Pigments in plants have several roles, e.g. photosynthesis and signaling. In its signalling function, colour is one of the oldest biological signs and it is used in a wide range of mutual interactions between plants and animals (Miller et al., 2009). These interactions have always been the object of studies aimed at understanding the complex ecological and evolutionary paths (Schaefer et al., 2004; Osório and Vorobyev, 2008). Flowers present a variety of resources such as colour, shape, scent, pollen and nectar to attract their pollinators, being colour and scent the first signs detected from a distance, and nectar and pollen rewards for the visit (Miller et al., 2009). When it comes to nectar-feeding birds, the attractiveness of a flower is characterised by a higher reflectance in the longer wavelengths, having a tubular shape and containing sucroserich nectar (Faegri and Van Der Pij1, 1979; Proctor et al., 1996; Wilson et al., 1994). Plants can use a wide range of resources regarding colour to attract a pollinating bird, such as the presence of coloured sepals, stamens, anthers, stigma and ovaries, besides petals that can present nectar guides and be multicoloured (Miller et al., 2009).

Measuring flower colour as it relates to a visiting pollinator requires that we consider the visual system of the animals (Gumbert et al., 1999; Osório and Vorobyev, 2008). In other words, the visual system of birds is far more complex (tetrachromatic, 300-700 nm photoreceptors) when compared to the human visual system (trichromatic, 400-700 nm photoreceptors). That is why the human perception of colours is different from that of birds (Cuthill et al., 2000; Altshuler, 2003). The diurnal birds' system is characterised by the presence of four to five photoreceptors (Varela et al., 1993), as well as oil droplets rich in carotenoids that can act as filters and improve the perception of the wavelength (Bowmaker et al., 1997, Hart et al., 2000; Osório and Vorobyev, 2008).

Pollinating animals use colours as a clue to make their choices about flowers to visit. Therefore, colours can help with plant species selection, flower location and ripeness and nectar and pollen location within the flower (Miller et al., 2009). Cuthill et al. (2000) and Bowmaker et al. (1997) showed lists of bird species related to the types of pigments present in the visual system and the spectral absorbance of each pigment. It was observed that all listed species presented pigments with high absorbance - between 500 and $575 \mathrm{~nm}$ - classified as long wavelength and only some species were ultraviolet-sensitive, as detected in some hummingbirds. The birds presenting a more complex visual system show a range of possible interactions with flowers of different tint. However, many studies have found that birds that interact with flowers show colour preference. Therefore, the relationship between flower colour and pollinator can vary greatly from highly specialised interaction to a generalist one (Wasern et al., 1996).

The objective of this study was to measure the true colour of flowers found in an urban area that are visited by nectarivorous birds. This required the measurement of reflectance considering the spectral range relevant to nectarivorous birds (between 300 and $700 \mathrm{~nm}$ ) and observation of the number of visits made to each flower species assessed.

\section{Material and Methods}

\subsection{Study area}

The study was carried out in the city of Taubaté, located in Vale do Paraíba, State of São Paulo, (45 33' 20" W and $23^{\circ} 01^{\prime} 35^{\prime \prime} \mathrm{S}$ ).

Observations were made in eight green areas (squares and parks) and 16 transects of $800 \mathrm{~m}$ along streets and avenues in the centre of the city. Individuals that presented flowers were identified and recorded as to their location. The biological material (flowers and fruits) were collected and the flowers were kept in $70 \%$ alcohol. These are stored in the collection of the University of Taubaté's Ecology Laboratory for future analyses and classification of the type of pollination syndrome. Lorenzi (2002a, b) and Lorenzi and Torres (2003) were used in the classification and nomenclature.

Green areas and transects were monthly visited over one year, from August 2005 to August 2006. When a plant started its flowering period, observations were made regarding nectar-feeding birds visitation. That required at least four days of two-hour observation for each plant species. The number of individuals observed varied according to the plants display. In other words, three individuals were selected for isolated trees, whereas three groups were selected for shrubby species used as hedgerows or aggregated. 
For bird observation, the focal method was used and only those species that had their flowers visited more than once were included in this study, so as to avoid recording of unintentional visitation.

\subsection{Flower reflectance analysis}

In order to measure reflectance, flowers were collected in the morning - between 5:00 AM and 7:00 AM - so as to avoid the hottest times, for, according to Miller et al. (2009), temperature influences the colour of the flower. The samples were immediately placed in wet plastic bags to avoid change in the turgor and temperature of the flowers. Reading started at 8:00 AM.

Flowers were collected of at least three individuals chosen due to their accessibility. For the analysis, the number of flowers varied according to the species in order to fill up the spectroradiometer field of view (Figure 1). Initially, the flowers were classified according to the number of colours they showed - monochrome, bicolour or tricolour - according to the in situ observations. Afterwards, flowers were taken to the Institute of Advanced Studies Laboratory at the Aerospace Technology Center. The measurements were made using an Analytical Spectral Devices (ASD) FieldSpec Pro spectroradiometer with a spectral resolution of $3 \mathrm{~nm}$ and a spectral range of 350-2,500 nm.

For the reflectance analysis, only the measurements in the wavelength ranging from Ultraviolet (UV) to the boundary between visible and infrared (350-700 nm) were used. The reflectance rate was calculated by dividing the flower's radiance by the radiance of a standard white made of Spectralon. Each flower was measured three times, and based on these measurements the median reflectance and standard deviation were calculated. Reflectance was also measured when the flowers were bicolour and, whenever possible, separate measures were taken, for example, inner and outer parts. For each species the median point was calculated, such as the wavelength that separates the spectrum into two parts of equal intensity, which, according to Altshuler (2003), is the point where birds detect the highest intensity of light.
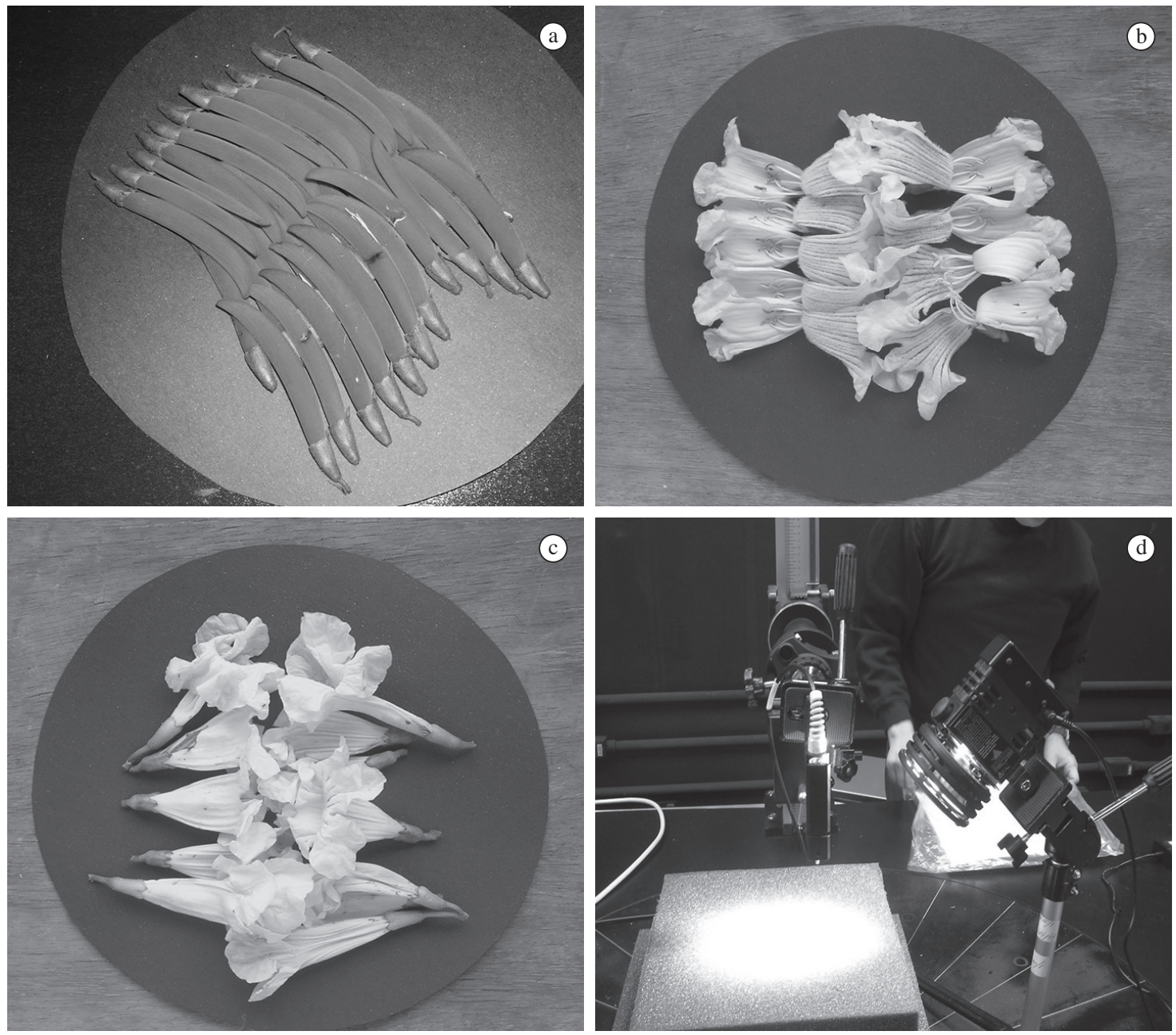

Figure 1. Photographs of the preparation of flowers for spectroradiometer analysis. a) Erythrina speciosa; b) Inner Tabebuia ochracea; c) Outer Tabebuia ochracea and d) spectroradiometer field of view. 


\section{Results}

Five nectar-feeding species were recorded: Eupetomena macroura (Gmelin, 1788), Amazilia lactea (Lesson, 1832), Chlorostilbon aureoventris (d'Orbigny and Lafresnaye, 1838), Thraupis sayaca (Linnaeus, 1766) and Coereba flaveola (Lineu, 1758). Three of them belong to the Trochilidae family and the last two belong to the Thraupidae and Coerebidae families, respectively. Among the species observed, E. macroura and C. flaveola were the most frequent in flower visitation, followed by A. lactea and C. flaveola.

As for plant species, 12 species were recorded with flowers visited by nectarivorous birds, including Malvaviscus aboreus Cav., Erythrina speciosa Tod., Bauhinia purpurea L., Grevillea banksii R. Br., Justicia brandegeana Wassh. and L.B.Sm., Tecoma stans (L.) Juss ex Kunth, Pachytachys lutea Nees, Chorisia speciosa A. St. -Hil., Prunus campanulata (Maxin.), Tabebuia impetiginosa (Mart. ex DC.) Standl., Tabebuia ochracea A. H. Gentry and Bauhinia variegata L., considering that the last species was divided into light pink flowers (LP) and white flowers (W) (Table 1). The spectral curve was calculated from the reflectance measures, and then the median point was obtained for the flowers of each species (Figure 2). The median points of the curves ranged from 538 to $651 \mathrm{~nm}$. A. láctea visited more often flowers with average reflectance of $591 \pm 36.5 \mathrm{~nm}$. E. macroura visited a higher number of species and flowers with average reflectance of $615,2 \pm 29.6 \mathrm{~nm}$. Unlike the troquilídeos, C. flaveola was the most generalist, visiting from light pink B. variegata - with average wavelength of $587 \mathrm{~nm}-$ to M. arboreus - with median point of $651 \mathrm{~nm}$. M. arboreus $(651 \mathrm{~nm})$, G. banksii $(645 \mathrm{~nm})$ and E. speciosa $(634 \mathrm{~nm})$ were the species that reflected more intensely in red, from 40 to $50 \%$ of reflectance, and that also presented syndrome of ornithophily characterised by tubular corolla and outer reproductive organs.

It was observed that the most visited species obtained the median point of reflectance in red, like $M$. arboreus and T. impetiginosa with 651 and $628 \mathrm{~nm}$, respectively. However, both showed a reflectance peak of approximately $20 \%$ in the short wavelength between 400 and $450 \mathrm{~nm}$

Table 1. Flower trees recorded in the urban area visited by nectarivorous birds (Nec) and insects (Ins). Measures of median reflectance, besides information regarding flowering period, number of colours pursuant to human vision: mono or bi (out $=$ outer color, inn $=$ inner colour) and species origin .

\begin{tabular}{|c|c|c|c|c|c|c|c|}
\hline Plant species & $\begin{array}{c}\text { Flowering } \\
\text { period }\end{array}$ & Colour & Origin & Syndrome & $\begin{array}{c}\text { Median } \lambda \\
(\mathbf{n m})\end{array}$ & $\begin{array}{c}\text { Visiting bird } \\
\text { species }\end{array}$ & $\begin{array}{c}\text { Average number/ } \\
\text { DP of visits }\end{array}$ \\
\hline $\begin{array}{l}\text { Malvaviscus } \\
\text { arboreus }\end{array}$ & Jan.-Jan. & mono & Mexico & $\mathrm{Nec}$ & 651 & $\begin{array}{c}\text { E. macroura } \\
\text { A. lactea } \\
\text { C. flaveola }\end{array}$ & $\begin{array}{l}4.85 \pm 3.15 \\
5.28 \pm 3.72 \\
4.30 \pm 3.58\end{array}$ \\
\hline Erythrina speciosa & June-Sep. & mono & Brazil & $\mathrm{Nec}$ & 645 & E. macroura & $3.50 \pm 1.29$ \\
\hline Bauhinia purpurea & Mar.-Aug. & bi & India & Ins/Nec & 638 & E. macroura & $1.60 \pm 1.99$ \\
\hline Grevillea banksii & Jan.-Jan. & bi & Australia & $\mathrm{Nec}$ & 634 & E. macroura & $2.00 \pm 0.82$ \\
\hline $\begin{array}{l}\text { Justicia } \\
\text { brandegeana }\end{array}$ & Jan.-Jan. & bi & Mexico & $\mathrm{Nec}$ & $\begin{array}{l}\text { 538-flor } \\
\text { 631-brac }\end{array}$ & A. lactea & $6.50 \pm 3.11$ \\
\hline Tecoma stans & Sep.-June & mono & Brazil & Ins/Nec & 611 & E. macroura & $0.75 \pm 0.96$ \\
\hline Pachystachys lutea & Sep.-Feb. & bi & Peru & $\mathrm{Nec}$ & 611 & A. lactea & $1.75 \pm 0.96$ \\
\hline Chorisia speciosa & Dec.-Apr. & bi & Brazil & Ins/Nec & 609 & E. macroura & $2.25 \pm 2.54$ \\
\hline $\begin{array}{l}\text { Prunus } \\
\text { campanelata }\end{array}$ & May-Aug. & mono & Japan & Ins/Nec & 608 & C. aureoventris & $1.00 \pm 0.82$ \\
\hline $\begin{array}{l}\text { Tabebuia } \\
\text { impetiginosa }\end{array}$ & May-Aug. & bi & Brazil & Ins/Nec & $\begin{array}{l}\text { 601-inn } \\
628 \text {-out }\end{array}$ & $\begin{array}{c}\text { E. macroura } \\
\text { A. lactea }\end{array}$ & $\begin{array}{l}8.75 \pm 2.75 \\
2.75 \pm 0.50\end{array}$ \\
\hline & & & & & & $\begin{array}{l}\text { C. flaveola } \\
\text { T. sayaca }\end{array}$ & $\begin{array}{l}8.75 \pm 6.24 \\
1.75 \pm 2.06\end{array}$ \\
\hline Tabebuia ochracea & June-Sep. & mono & Brazil & $\mathrm{Ins} / \mathrm{Nec}$ & 591 & $\begin{array}{c}\text { E. macroura } \\
\text { A. lactea } \\
\text { C. flaveola } \\
\text { T. sayaca }\end{array}$ & $\begin{array}{l}2.75 \pm 3.92 \\
5.50 \pm 3.74 \\
5.75 \pm 6.71 \\
0.50 \pm 1.00\end{array}$ \\
\hline Bauhinia variegata & July-Sep. & bi & India & Ins/Nec & 587 & $\begin{array}{c}\text { E. macroura } \\
\text { A. lactea } \\
\text { C. flaveola }\end{array}$ & $\begin{array}{l}2.54 \pm 2.30 \\
1.00 \pm 1.29 \\
2.43 \pm 2.30\end{array}$ \\
\hline Bauhinia variegata & July-Sep. & mono & India & Ins/Nec & 558 & $\begin{array}{c}\text { A. lactea } \\
\text { E. macroura }\end{array}$ & $\begin{array}{l}3.08 \pm 3.07 \\
0.71 \pm 0.73\end{array}$ \\
\hline
\end{tabular}


(Figure 2b, d). J. brandegeana was visited only by A. lactea. It should be noted that this flower presents white colour and nectar guide that resulted in $20 \%$ reflectance in all the spectrum, that is, 350 to $700 \mathrm{~nm}$ (Figure 2c).

The yellow flowers of $T$. ochracea were the third most visited by the birds and also showed a differentiated signature. Between 550 and $700 \mathrm{~nm}$, they showed a $80 \%$ reflectance and at $350 \mathrm{~nm}$ the reflection intensity was about $37 \%$ and almost no reflection in blue and green wavelengths. This behaviour made median point of reflection of this species drop to $589 \mathrm{~nm}$. As for the yellow species, the least visited, were $T$. stans and $P$. lútea, which showed a spectral signature similar to $T$. ochracea, although at low intensity, between 0.2 and 0.4 (Figure 2e), respectively.
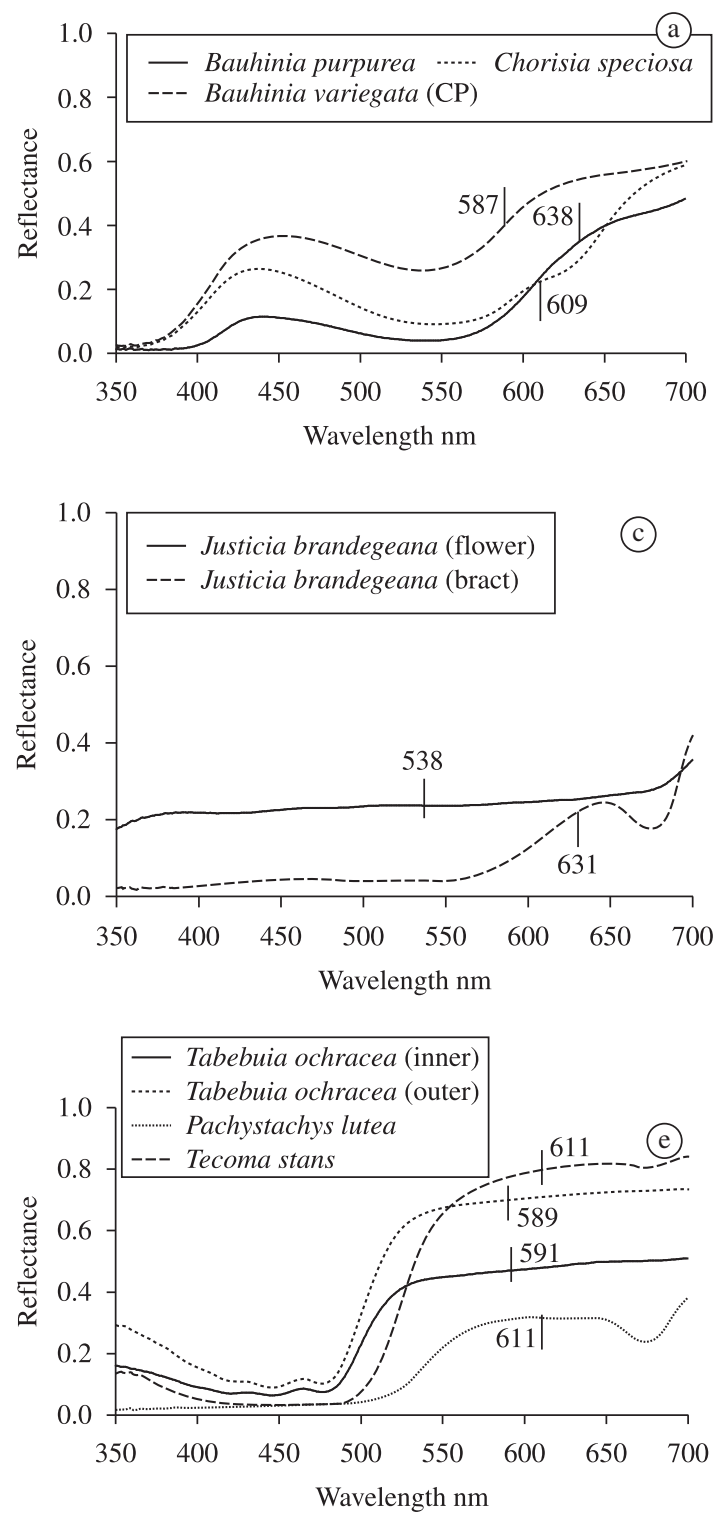

The white flowers species - B. variegata and $J$. brandegeana - were the species that showed the lowest median values, $538 \mathrm{~nm}$ and $558 \mathrm{~nm}$, respectively. It was observed that white flowers were the most visited by A. lactea.

As for bicolour species, consisting of two parts with distinct colors, the reflectance curves of both parts were obtained separately. That is what occurred to T. impetiginosa, whose outer part is lilac and has yellow nectar-guide, and J. brandegeana, which has red bracts and white flowers with nectar-guide formed by brown spots (Figure $2 \mathrm{a}, \mathrm{b}$ ). The result obtained showed that the outer part of both species reflect mostly in the longer wavelengths (J. brandegeana: $631 \mathrm{~nm}$ and bract of T. impetiginosa: $628 \mathrm{~nm}$ ), and the
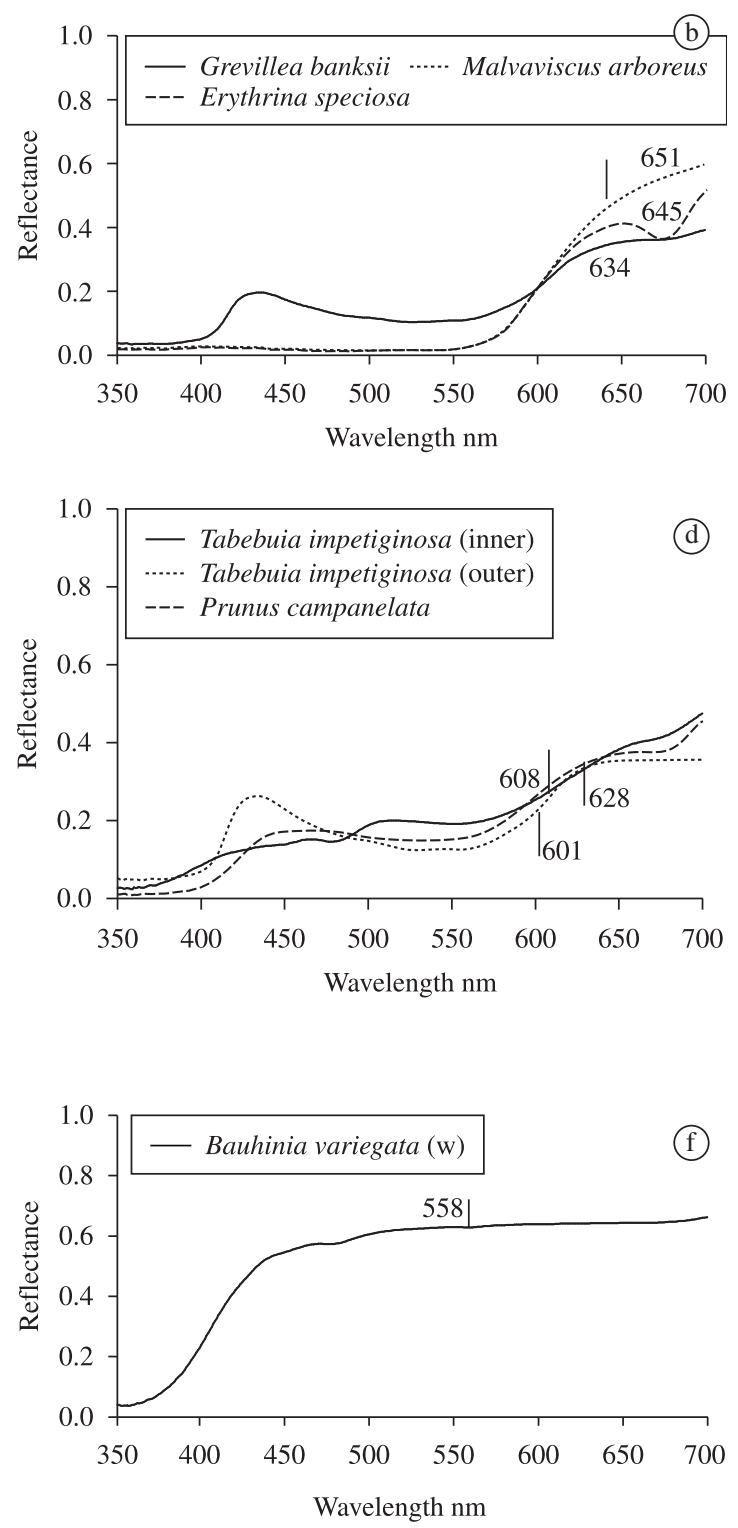

Figure 2. Reflectance curve of the most abundant flowers in urban areas that are visited by nectar-feeding birds; a) magenta; b) red; c) J. brandegeana, flower and bract; d) lilac (T. impetiginosa, inner and outer); e) yellow; and f) white. 
inner parts reflect mostly in the shorter wavelengths (J. brandegeana: $538 \mathrm{~nm}$ and T. impetiginosa: $601 \mathrm{~nm}$ ). It is worth noting that these two species were the most visited by $A$. lactea.

\section{Discussion}

Survey results of the colour of flowers visited by nectar-feeding birds showed that flowers reflecting long wavelength were the most visited by Trochillideos present in the urban centre and that flowers with higher reflectance rate (above $600 \mathrm{~nm}$ ) were strongly associated with bird pollination. An analysis carried out in the visual systems of Sephanoides sephanoides (Lesson, 1827) and Oreotrochilus leucopleurus (Gould, 1847) showed the sensitivity to short wavelength like blue was low, thus providing evidence to the hypothesis that higher visual sensitivity is associated with long wavelength (Herrera et al., 2004). Altshuler (2003) has also achieved similar results regarding the wavelength more intensely reflected by flowers used by hummingbirds. The author has assessed the reflectance rate and median reflectance values of 92 species belonging to 28 families of tropical forest plants. $69 \%$ of flowers presented parts reflecting exclusively in long wavelength, such as red, orange and yellow. Red flowers presented reflectance curve median between 610 and $665 \mathrm{~nm}$; yellow flowers presented median value between 564 and $624 \mathrm{~nm}$, and their colours were mixed with red.

Findings of this work showed that flowers reflecting in ultraviolet were rare and little visited. Results obtained by Altshuler (2003) corroborate the results of the present work, since the author has also found that the reflected UV is unusual in the flowers analysed in four tropical forests.

Flowers reflecting in short and medium wavelengths (350 to $600 \mathrm{~nm}$ ) are usually pollinated by insects, but can be visited by birds (Altshuler, 2003), mainly the most generalist species, such as C. flaveola (Mata and Bosque, 2004). Some bird species, including nectar-feeding birds, can detect ultraviolet due to their tetrachromatic vision covering ultraviolet, blue, green and red (Bowmaker et al., 1997). Yellow flowers, such as T. ochracea, T. stans and P. lútea, presented a reflectance peak in ultraviolet, characterising insect pollination, since many insects, including bees, are trichromats based on ultraviolet, blue and green (Peitsch et al., 1992). Nevertheless, T. stans and P. lútea were little visited as compared to $T$. ochracea, probably due to a change in colour constancy of the flower. According to Kevan et al. (2001), changes in spectral distribution in ambient light may cause the eyes of nectar-feeding species to mistake similar signals, thus resulting in visits to other flower species.

On the other hand, the flower conspicuity may change due to the wavelength prevailing in the habitat, that is, environment with indirect light (beneath the canopy) have their wavelength predominantly green $(560 \mathrm{~nm})$, mainly due to leaves' reflectance (Altshuler, 2001). In predominantly green environment, complementary colours like lilac and red tend to be more conspicuous (Miller, RS. and Miller, RE., 1971; Altshuler, 2001, 2003).

Unlike in forests, green is not the prevailing colour in urban areas, and the spectral distribution in ambient light can vary greatly due to constructions, artificial lighting, painting and other signs that make up the urban landscape. Therefore, deeper studies are required in urban areas to enhance the knowledge about more attractive plant species, not only for birds but for all nectar-feeding vertebrate and invertebrate animals so as to contribute to increasing the urban biodiversity.

In conclusion, the most visited flower colours were those presenting red, lilac and yellow. However, E. macroura visited more often the species reflecting in red and the A. lactea and C. aureoventris visited the flowers with short wavelength reflectance, such as ultraviolet, blue and green. As for $C$. flaveola and T. sayaca, their behaviour did not seem to be associated with colour, but with availability of food. As a rule, urban nectar-feeding birds presented little specificity regarding colour. Therefore, another hypothesis should be investigated, such as floral nectar quantity and quality and competition.

\section{References}

ALTSHULER, DL., 2001. Ultraviolet reflectance in fruits, ambient light composition, and fruit removal in a tropical forest. Evolutionary Ecology Research, vol.3, no.7, p. 767-778.

ALTSHULER, DL., 2003. Flower Color, Hummingbird Pollination, and Habitat Irradiance in Four Neotropical Forests. Biotropica, vol. 35 , no. 3, p. 344-355.

BEISSINGER, SR. and OSBORNE, DR., 1982. Effects of urbanization on avian community organization. Condor, vol. 84, no. 1, p. $72-83$.

BOWMAKER, JK., HEATH, LA., WILKIE, SE. and HUNT, DM., 1997. Visual Pigments and Oil Droplets from Six Classes of Photoreceptor in the Retinas of Birds. Vision Research, vol. 37 , no. 16, p. 2183-2194.

CLERGEAU, P., SAVARD, J., MENNECHEZ, G. and FALARDEAU, G., 1998. Bird abundance and diversity along an urban rural gradient: a comparative study between two cities on different continents. Condor, vol. 100, no. 3, p. 413-425.

CUTHILL, IC., PARTRIDGE, CJ., BENNETT, ATD., CHURCH, SC., HART, NS. and HUNT, S., 2000. Ultraviolet vision in birds. Advances in the Study of Behaviour, vol. 29, p. 159-214. doi:10.1016/S0065-3454(08)60105-9

DAVIS, AM. and GLICK, TF., 1978. Urban ecosystems and island biogeography. Environmental Conservation, vol. 5, no. 4, p. 299-304.

DEGRAAF, RM., 1985. Residential forest structure in urban and suburban environments: some wildlife implications in New England. Journal of Arboriculture, vol. 11, no. 8, p. 236-241.

FAEGRI, K., and VAN DER PIJL., 1979. The principles of pollination ecology. New York: Pergamon. 244 p.

FRENCH K., MAJOR R. and HELY, K., 2005. Use of native and exotic garden plants by suburban nectarivorous birds. Biological Conservation, vol. 121 , p. 545-559 
GREEN, RJ., 1984. Native and exotic birds in a suburban habitat. Australian Wildlife Research, vol. 11, no. 1, p. 181-191.

GUMBER, A., KUNZE, J. and CHITTKA, L., 1999. Floral colour diversity in plant communities, bee colour space and a null model. Proceedings of the Royal Society, vol. 266, no. 1429, p. 1711-1716.

HART, NS., PARTRIDGIE, JC., CUTHILLAN, C. and BENNETT, DATD., 2000. Visual pigments, oil droplets, ocular media and cone photoreceptor distribution in two species of passerine bird: the Blue Tit (Parus cuerukus L.) and the Blackbird (Turdus merukz L.). Journal of Comparative Physiology A, vol. 186, no. 4 , p. 375-387.

HERRERA, G., FERÁNDEZ MJ., POHL, N., DIAZ, M., BOZINOVIC, F. and PALACIOS, A., 2004. Sistema visual en el Colibrí austral (Sephanoides sephanoides) y el picaflor cordillerano (Orotrochilus leucopleurus) electrorretinografia y coloración. Ornitología Neotropical, vol. 15, p. 215-222.

KEVAN, PG., CHITTKA, L., and DRYER, AG., 2001. Limits to the salience of ultraviolet: lessons from colour vision in bees and birds. The Journal of Experimental Biology, vol. 204, no. 14, p. 2571-2580.

LORENZI, H. and TORRES, HM., 2003. Árvores exóticas no Brasil: madeiras, ornamentais e aromáticas. Nova Odessa: Instituto Plantarum. 368 p.

LORENZI, H., 2002. Árvores brasileiras: manual de identificação e cultivo de plantas arbóreas nativas do Brasil. 2 ed. Odessa: Instituto Plantarum. 352 p.

LORENZI, H., 2002. Árvores brasileiras: manual de identificação e cultivo de plantas arbóreas nativas do Brasil. 2 ed. Odessa: Instituto Plantarum. 368 p.

MATA, A. and BOSQUE, C., 2004. Sugar preferences, absorption efficiency and water influx in a Neotropical nectarivorous passerine, the Bananaquit (Coereba flaveola). Comparative Biochemistry and Physiology, Part A, vol. 139, no. 3, p. 395-404.

MENDONÇA, LB. and ANJOS, L. dos, 2005. Beija-flores (Aves, Trochilidae) e seus recursos florais em uma área urbana do Sul do Brasil. Revista Brasileira de Zoologia, vol. 22, no. 1, p. 51-59.
MILLER, R., OWENS, SJ. and RORSLETT, B., 2009. Plants and colour: flowers and pollination. Optics \& LaserTechnology, in press.

MILLER, RS. and MILLER, RE., 1971. Feeding activity and color preference of ruby-throated hummingbirds. The Condor, vol. 73, no. 3, p. 309-313.

OSORIO, D. and VOROBYEV, M., 2008. A review of the evolution of animal colour vision and visual communication signals. Vision Research, vol. 48, no. 20, p. 2042-2051.

PEITSCH, D., FIETZ, A., HERTEL, H., SOUZA, J. de, VENTURA, DF. and MENZEL, R., 1992. The spectral input systems of hymenopteran insects and their receptor-based colour vision. Journal of Comparative Physiology A, vol. 170, no. 1, p. 23-40.

PROCTOR, MCF., YEO, P. and LACK, A., 1996. The natural history of the pollination. Portland: Timber Press.

ROCCA, MA. and SAZIMA, M., 2008. Ornithophilous canopy species in the Atlantic rain forest of southeastern Brazil. Journal of Field Ornithology, vol. 79, no. 2, p. 130-137.

SCHAEFER, HM., SCHAEFER, V. and LEVEY, DJ., 2004. How plant-animal interactions signal new insights in communication. TRENDS in Ecology and Evolution, vol. 19, no. 11 , p. $577-584$

SICK, H., 1997. Ornitologia Brasileira. Rio de Janeiro: Editora Nova Fronteira. 912p.

TOLEDO, MCB. and MOREIRA, DM. 2008. Analysis of feeding habitats of the swallow-tailed hummingbird, Eupetomena macroura (Gmelin, 1788), in an urban park in southeastern Brazil. Brazilian Journal Biology, vol. 68, no. 2, p. 419-426.

VARELA, FJ., PALACIOS, AG. and GOLDSMITH, TH., 1993. Color vision in birds. 76-98. In ZEIGLER, HP. and BISCHOF, HJ., eds. Vision, brain, and behavior in birds. Cambridge: MIT.

WASERN, ML, CHITTKA, PRICE, MV., WILLIAMAS, NM. and OLLERTON, DJ., 1996. Generalization in pollination systems, and why it matters. Ecology, vol. 477, no. 4, p. 1043-1060. 